\title{
GREATER FOOD AVAILABILITY REDUCES TARSUS ASYMMETRY IN NESTLING BLUE TITS
}

\author{
FABRIZIO GRIECO ${ }^{1}$ \\ Netherlands Institute of Ecology, Centre for Terrestrial Ecology, P.O. Box 40, \\ NL 6666 GA Heteren, Netherlands
}

\begin{abstract}
Previous work has shown that the quantity or quality of food affects the degree of asymmetry in bilateral body traits in adult birds, but so far there is no evidence that this is the case in early phases of growth too. I studied asymmetry of tarsus length of nestling Blue Tits (Parus caeruleus) in relation to supplemental feeding. I offered food, in the form of mealworms (Tenebrio molitor) and wax moth (Galleria mellonella) larvae, to the adults during the brood-rearing period. The parents consumed the extra food themselves and fed the brood an amount corresponding to one-third of the brood's total food intake. Food supplementation resulted in reduced asymmetry of nestling tarsus length, indicating that body asymmetry in early phases of life, not only in adult birds, depends on energy or protein intake.
\end{abstract}

Key words: breeding, developmental stability, $\mathrm{Pa}-$ rus caeruleus, supplemental feeding experiment, symmetry.

Mayor Disponibilidad de Alimento Reduce la Asimetría del Tarso en Polluelos de Parus caeruleus

Resumen. Investigaciones previas han demostrado que la cantidad o calidad de alimento disponible afecta al grado de asimetría bilateral de rasgos corporales en aves adultas, pero hasta ahora no se ha demostrado si este proceso también sucede en las fases tempranas del crecimiento. En este estudio investigué la asimetría de la longitud del tarso en polluelos de Parus caeruleus con relación a la administración de una dieta suplementaria. Se ofreció alimento a los adultos durante el periodo de cría en forma de larvas de escarabajo de la harina y larvas de polilla de la cera. Los padres consumieron el alimento adicional y entregaron una cantidad correspondiente a un tercio de la ingesta total de alimento de los polluelos. El suplemento de alimento resultó en una reducción significativa en la asimetría de la longitud del tarso de los polluelos, indicando que el estrés ambiental mediado por el comportamiento de aprovisionamiento efectuado por los padres afecta a la

Manuscript received 15 August 2002; accepted 7 April 2003.

${ }^{1}$ Present address: Pomona 418, NL 6708 CR Wageningen, Netherlands. E-mail: fabgrieco@ hetnet.nl asimetría del desarrollo corporal en fases tempranas de la vida.

In birds, bilateral traits like tarsi and flight feathers are expected to be identical in size on the two sides (left and right), as they are assumed to be under control of the same genome and environment. However, this symmetry is rarely the case. Bilateral structures have been found to be more or less asymmetrical because of environmental (Hoffmann and Parsons 1991, Parsons 1992) or genetic stress (Palmer and Strobeck 1986, Leary and Allendorf 1989, Parsons 1990, 1992). Fluctuating asymmetry (Ludwig 1932, van Valen 1962, Palmer and Strobeck 1986) refers to small, random deviations from perfect symmetry of bilateral traits and is assumed to be a measure of the ability of an organism to develop bilateral characters identically (developmental stability; Zakharov 1992). Most studies on the effects of environmental stress on fluctuating asymmetry are correlative, and, among the experimental ones, very few have investigated the effect of food (with the exception of some studies on insects; Bjorksten et al. 2000). In birds, food availability is known to affect feather asymmetry in adults (Swaddle and Witter 1994, Nilsson 1994); however, it is still unclear whether that is the case for birds in early phases of life, especially in natural conditions. In a recent book on growth in birds (Starck and Ricklefs 1998), the terms "asymmetry" and "fluctuating asymmetry" do not even appear in the subject index. Hovorka and Robertson (2000) found no evidence for an effect of food deprivation on body asymmetry of nestling Tree Swallows (Tachycineta bicolor). It is clear that we need more studies that investigate the mechanisms that give rise to developmental instability, particularly by manipulating behaviorally mediated environmental stress.

In this study, I examine the effects of food availability on the asymmetry of tarsi in nestling Blue Tits (Parus caeruleus). The reproductive success of this species depends on the abundance of insect food, primarily caterpillars, which varies markedly during the breeding season (Gibb and Betts 1963, Nur 1984, Perrins 1991). Especially when the adults raise their brood well before or after the peak period of caterpillar abundance, food stress is likely to increase the degree of body asymmetry, because fewer resources are directed to the control of developmental precision. An experimental increase in food availability is predicted 
to decrease asymmetry of bilateral characters (Nilsson 1994).

To increase food availability to the nestlings, I provided additional food to the adults in the brood-rearing phase. The parents could either give the supplemented food to the nestlings or eat it themselves. In the latter case, the brood could still benefit from the added food, because the parents would allocate more time to food provisioning, resulting in greater rates of food delivery to the nest (Grieco 2002). In the year I did this study, food-supplemented adults brought to the nest $0.06 \pm$ 0.01 (SE) g dry mass nestling ${ }^{-1} \mathrm{hr}^{-1}$, significantly more than control, unfed adults $(0.04 \pm 0.01 \mathrm{~g}$ nestling $^{-1} \mathrm{hr}^{-1}$; Grieco 2002). Therefore, nestlings in foodsupplemented nests were expected to grow in better conditions, with positive effects on their body symmetry.

\section{METHODS}

The study was carried out in 1999 in the National Park "De Hoge Veluwe" $\left(52^{\circ} 1^{\prime} \mathrm{N}, 5^{\circ} 52^{\prime} \mathrm{E}\right)$, central Netherlands, in mixed deciduous forest patches provided with nest boxes. The patches grew on poor sandy soil and were dominated by Scots pine (Pinus sylvestris), European oak (Quercus robur), and birch (Betula pendula), with some occurrence of American oak (Quercus borealis) and beech (Fagus sylvatica; van Balen 1973). The study area contains 400 nest boxes.

\section{SUPPLEMENTAL FEEDING EXPERIMENT}

Mealworms (Coleoptera: Tenebrio molitor) and larvae of wax moth (Lepidoptera: Galleria mellonella) were placed in small feeding trays $(5.5 \times 3.5 \times 4.5 \mathrm{~cm})$ inside the nest boxes from the date of hatching of the first egg (day 0) to the date of fledging of the young. At early chick ages (day 0 to 6), food consisted of a mixture of the two species; subsequently it was composed of mealworms only. The quantity of food supplied daily corresponded to about one-half of the brood's daily requirement as reported by Gibb and Betts (1963). The variation in this amount across nestling ages was calculated by taking into account that natural food consumption increases linearly with nestling age and then levels off around the middle of the nestling stage (as reported by van Balen 1973 for the Great Tit [Parus major]). I calculated several curves of food amount versus nestling age depending on brood size. For a 12-chick brood, the food amount offered increased approximately linearly from day 0 to day 10, and then leveled off around $20 \mathrm{~g} \mathrm{day}^{-1}$. For smaller and larger broods I calculated food amounts proportionally: amount for $n$-chick brood $=$ (amount of 12-chick brood/12) $\times n$; (more details in Grieco 2002). Feeding trays were replenished each day according to the scheduled amount. Half of the boxes were food supplemented $(n=11)$, while the other half were not and served as controls $(n=11)$. All control nest boxes were at least $50 \mathrm{~m}$ from the nearest foodsupplemented one, so it is very unlikely that control adults had access to the food added. In addition, video recording at the nest (see below) suggested that control adults never entered food-supplemented nest boxes. Food-supplemented and control boxes were chosen randomly within pairs having similar hatching dates. I assigned different treatment levels to boxes in similar habitats whenever possible. I classified habitats in wood plots according to the dominant tree species: birch, European oak, mixed European oak and pine, or American oak. Nests of the two treatment groups were represented in those habitats at similar frequencies (number of nests [control:food-supplemented]: birch 1: 2 , European oak $3: 4$, mixed 7:4, American oak $0: 1 ; \chi^{2}{ }_{3}$ $=2.3, P=0.51$ ).

For all nests, I videotaped the adults feeding the young. A Sony CCD-TR825E videocamera was placed facing down from the top of the open nestbox. During filming, a wooden box covered the videocamera, while a small lamp placed behind it provided more light in the nest. Nests were filmed twice for $90 \mathrm{~min}$ each, the first when the nestlings were 3 to 7 (mean 5.6) days old, the second when they were 9 to 14 (mean 11.5) days old (Grieco 2002). Videotapes were analyzed to assess the rate of consumption of supplemental food.

\section{MORPHOMETRY}

I measured left and right tarsi of all nestlings at 10 and 14 days after hatching. Measurements were not blind; that is, at the moment of measurement I was aware of which experimental group the nestling belonged to. Asymmetry was defined as the unsigned difference between the right and the left side (|right-left|). This index included measurement error since I did not take multiple measurements. Thus, it cannot distinguish between measurement error and true fluctuating asymmetry (Swaddle et al. 1994). At both nestling ages, the signed differences $(\mathrm{R}-\mathrm{L})$ were distributed normally (Shapiro-Wilk tests, $P>0.10$ ), their means did not depart significantly from zero (one-sample $t$-tests, max. $\left.t_{19}=0.6, P=0.54\right)$, and were not correlated with trait size within nestling age (correlations, max. $r=-0.2$, $n=20, P=0.34)$. Therefore, no size correction of asymmetry index was applied.

\section{STATISTICAL ANALYSES}

I estimated repeatability of tarsus measurements (left and right side) following Lessells and Boag (1987) for the average and Becker (1984) for the standard error. Tarsus asymmetry was analyzed with repeated-measures ANCOVA in Statistica for Windows version 5.5 (StatSoft 1999), where nestling age (expressed in days after hatching) was the repeated-measures factor. Nests were the unit of observations, and average measures per nest were entered in the analysis. Hatching date (expressed as April date, $1=1$ April, $31=1$ May), average tarsus length at day 10 and day 14, and brood size at day 10 were entered in the models as covariates, and were excluded if not significant to test for the significance of the effect of food addition. Tarsus length was normally distributed, while unsigned asymmetry was not and therefore was $\log$ transformed $\left(y^{\prime}=\log [y\right.$ $+0.5])$.

Of the 22 broods initially studied, one was abandoned by the parents at hatching, and another was unusually small. I excluded these nests from analysis, resulting in 20 total nests (10 in each experimental group). Variables are reported as means \pm SE. Control and food-supplemented broods did not differ in hatching date, tarsus length at day 10 and 14 or brood size ( $t$-tests, max. $t_{18}=1.7, P=0.12$ ). 
TABLE 1. Repeatability estimates $(r)$ of tarsus length in Blue Tit nestlings for two ages posthatching in foodsupplemented and control nests. Repeatability was calculated from a one-way ANOVA with individual as a factor $(n=$ number of nestlings). Tarsus length was entered as deviation from the nest average. Repeatability estimates did not differ between control and food-supplemented nests ( $t$-tests within age classes, max. $t_{130}=$ $-0.22, P=0.17)$.

\begin{tabular}{lccccc}
\hline \hline $\begin{array}{l}\text { Day } \\
\text { Treatment }\end{array}$ & $n$ & $r \pm \mathrm{SE}$ & $\mathrm{df}$ & $F$ & $P$ \\
\hline Day 10 & & & & & \\
$\quad$ Control & 67 & $0.95 \pm 0.01$ & 66,67 & 39.7 & $<0.001$ \\
$\quad$ Food-supplemented & 65 & $0.94 \pm 0.01$ & 64,65 & 33.9 & $<0.001$ \\
Day 14 & & & & \\
$\quad$ Control & 67 & $0.87 \pm 0.03$ & 66,67 & 13.9 & $<0.001$ \\
$\quad$ Food-supplemented & 65 & $0.92 \pm 0.02$ & 64,65 & 22.9 & $<0.001$ \\
\hline
\end{tabular}

\section{RESULTS}

\section{FOOD CONSUMPTION}

The parents took all larvae offered daily in $183(89 \%)$ of the 205 nest-feeding days $(n=10$ food-supplemented nests). When the young approached fledging (17-20 days after hatching), mealworms were found during the check of nestboxes on the subsequent day, suggesting that the amount offered at that stage exceeded the need of the parents and the brood. During videotaping sessions, the adults took on average 21.5

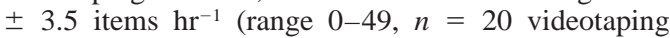
sessions). However, the adults delivered to their young only $35 \pm 7 \%$ (range $0-100 \%, n=19$ ) of the food items taken from the tray. As a result, the broods received $16.3 \pm 3.5(n=20)$ extra food items $\mathrm{hr}^{-1}$, which corresponded to approximately one-third of the total food amount consumed (estimate: $0.06 \pm 0.01 \mathrm{~g}$ dry mass nestling ${ }^{-1} \mathrm{hr}^{-1}$; Grieco 2002).

EFFECTS OF FOOD SUPPLEMENTATION

Tarsus length was highly repeatable, and repeatability did not differ between control and food-supplemented

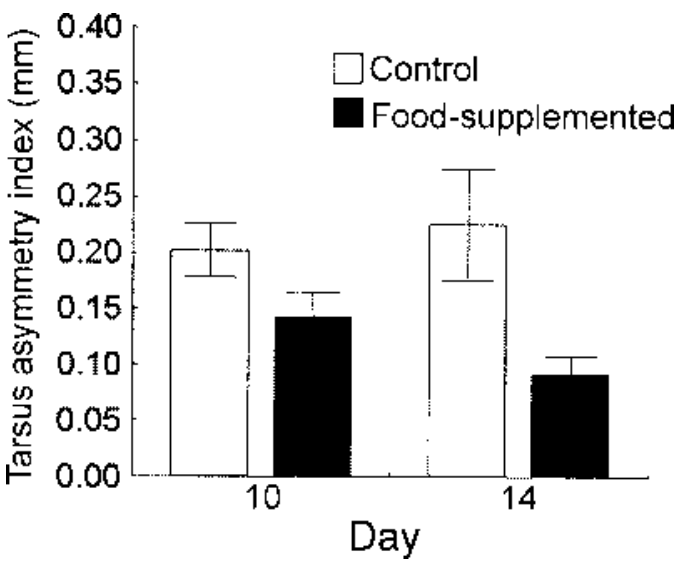

FIGURE 1. Degree of asymmetry of tarsus length of Blue Tit nestlings in control and food-supplemented nests, at 10 and 14 days after hatching. Sample size is 10 nests for each group. nests (Table 1), suggesting that the measurement error was similar between nestlings of the two groups.

Food supplementation did not result in greater skeletal size of nestlings before fledging. The tarsi of foodsupplemented nestlings were similar in length to those of control nestlings (repeated measures ANCOVA, effect of food addition, $F_{1,18}=2.3, P=0.15$ ). However, tarsi of food-supplemented nestlings were more symmetrical than those of control nestlings, both at day 10 and day 14 after hatching (Fig. 1; repeated measures ANCOVA, effect of food addition, $F_{1,18}=8.9, P<$ 0.01 ; food addition $\times$ nestling age interaction, $F_{1,18}=$ $1.9, P=0.18)$. The degree of asymmetry did not change significantly with nestling age $\left(F_{1,18}=0.7, P\right.$ $=0.40$; this was also the case when expressing asymmetry relative to trait size). Brood size, tarsus length, and hatching date did not affect tarsus asymmetry (repeated measures ANCOVA, all $P>0.09$ ). Thus, food supplementation reduced asymmetry of tarsi in Blue Tit nestlings, independent of their developmental stage.

\section{DISCUSSION}

This study provides experimental evidence that asymmetry of tarsi is influenced by the feeding conditions in which nestlings grow. Food-supplemented Blue Tit nestlings had more symmetrical tarsi than controls, both when 10 and 14 days old. In Parus species tarsi generally grow until 14-15 days after hatching (O'Connor 1977, van Noordwijk et al. 1988, Kunz 1999), so the effect of food addition on tarsus asymmetry presumably persisted at least until fledging.

With this data set I could not properly estimate measurement error, which complicates the reliability of my measure of fluctuating asymmetry. However, the difference in tarsus asymmetry between the two experimental groups was highly significant, leaving few doubts on the effect of feeding conditions on tarsus asymmetry in nestling Blue Tits. It is possible that the higher degree of asymmetry in unfed control broods was the result of a greater measurement error in this group. However, the estimates of repeatability of tarsus length suggest that the magnitude of the measurement error was similar between control and food-supplemented broods, indicating that the effect of food manipulation was not an artifact. 
Previous studied have provided contrasting evidence for an effect of food abundance on body asymmetry. Björklund (1996) found that Blue Tit nestlings attended by only the female parent (and that presumably suffered food shortage; Sasvári 1986) had feathers as symmetrical as those in broods attended by two parents. Björklund (1996) concluded that food stress did not influence asymmetry in Blue Tits early in life, although he did not measure asymmetry in other traits. Swaddle and Witter (1994) found that the degree of primary-feather asymmetry in adult European Starlings (Sturnus vulgaris) was negatively correlated with an index of fat reserve, providing an indication that energetic stress plays a direct role in the development of asymmetry. The results of my study indicate that the quality or quantity of food affects the degree of body asymmetry in young birds too. More importantly, they show that environmental stress mediated by parental behavior influences asymmetry of a trait (tarsus length) that is likely to persist during life, and may have fitness consequences.

I failed to find an effect of nestling age on tarsus asymmetry. Nestlings in both experimental groups showed the same degree of asymmetry at day 10 and at day 14, when growth is assumed to be at its maximum. This contrasts with many empirical studies where asymmetry of certain traits decreases at the end of their development (Teather 1996, Møller and Swaddle 1997, Swaddle and Witter 1997, Aparicio 1998 2001), while other studies including those on bone growth have found increasing asymmetry with ontog eny (Chippindale and Palmer 1993, Hallgrímsson 1999, Tomkins 1999). This study suggests that much of the asymmetry of tarsi accumulates early in life (0 to 10 days after hatching) and does not decline at the end of growth. This agrees, at least in part, with patterns of asymmetry of bones in mammals, where asymmetry increases as long as the bones grow (Hallgrímsson 1999).

The causal link between increased food availability and greater symmetry remains unclear. Nestlings growing in better feeding conditions could allocate more resources to mechanisms of compensational growth that restore symmetry between the left and right tarsi. The existence of such active mechanisms of developmental control has been proposed to explain patterns of asymmetry with ontogeny (Swaddle and Witter 1997), but other processes could explain these patterns. The degree of asymmetry could not only depend on developmental errors at the microscopic level, but also on the stage of ontogeny at which the study takes place (Aparicio 1998, 2001). In the model by Aparicio (2001), traits that are more developed are expected to be more symmetric, because once the investment level reaches a certain value the high cost of growth would minimize the effect of developmental noise. However, in my study food-supplemented nestlings showed the same degree of development as control nestlings, as indicated by tarsus length. Therefore, a model that takes only the effect of ontogeny into account is less likely to explain the effect of food addition reported here, unless food addition somehow changes the shape of the relationship between investment level and trait size.
I thank the board of the National Park "De Hoge Veluwe" for permission to carry out this research. Comments by Niels Cadée, Martin Granbom and another referee improved previous versions. Arie van Noordwijk and Erik Postma gave advice about repeatability calculations. Silvia Perez provided the Spanish translation for the abstract. This study was part of a Ph.D project partly funded by the European Commission with a Marie Curie Research Fellowship (No. ERB FMBICT 971939).

\section{LITERATURE CITED}

Aparicio, J. M. 1998. Patterns of fluctuating asymmetry in developing primary feathers: a test of the compensational growth hypothesis. Proceedings of the Royal Society of London Series B 265: 2353-2357.

Aparicio, J. M. 2001. Patterns of growth and fluctuating asymmetry: the effects of asymmetrical investment in traits with determinate growth. Behavioral Ecology and Sociobiology 49:273-282.

BECKER, W. A. 1984. A manual of quantitative genetics. Academic Enterprises, Pullman, WA.

BJÖRKLUND, M. 1996. The effect of male presence on nestling growth and fluctuating asymmetry in the Blue Tit. Condor 98:172-175.

BJorksten, T. A., K. Fowler, and A. Pomiankowski. 2000. What does sexual trait FA tell us about stress? Trends in Ecology \& Evolution 15:163166.

Chippindale, A. K., AND A. R. Palmer. 1993. Persistence of subtle departures from symmetry over multiple molts in individual brachyuran crabs: relevance to developmental stability. Genetica 89 : 185-199.

GibB, J. A., AND M. M. BetTs. 1963. Food and food supply of nestling tits (Paridae) in Breckland pine. Journal of Animal Ecology 32:489-533.

GRIECO, F. 2002. How different foraging strategies result in equal food delivery rates: an experimental study on Blue Tits. Journal of Avian Biology 33: 331-341.

HALlGRímSSON, B. 1999. Ontogenetic patterning of skeletal fluctuating asymmetry in rhesus macaques and humans: evolutionary and developmental implications. International Journal of Primatology 20:121-151.

Hoffmann, A. A., And P. A. Parsons. 1991. Evolutionary genetics and environmental stress. Oxford University Press, Oxford, UK.

Hovorka, M. D., AND R. J. Robertson. 2000. Food stress, nestling growth and fluctuating asymmetry. Canadian Journal of Zoology 78:28-35.

KunZ, C. 1999. Genetic variation and phenotypic plasticity in body traits of nestling Blue Tits. Ph.D. dissertation, Uppsala University, Uppsala, Sweden.

LeAry, R. F., AND F. W. Allendorf. 1989. Fluctuating asymmetry as an indicator of stress: implications for conservation biology. Trends in Ecology \& Evolution 4:214-217.

Lessells, C. M., AND P. T. BoAg. 1987. Unrepeatable repeatabilities: a common mistake. Auk 104:116121. 
LudwIG, W. 1932. Das Links-Rechts Problem im Tierreich und beim Menschen. Springer Verlag, Berlin.

Møller, A. P., And J. P. Swaddle. 1997. Asymmetry, developmental stability and evolution. Oxford University Press, Oxford, UK.

NILSSON, J.-A. 1994. Energetic stress and the degree of fluctuating asymmetry: implications for a longlasting, honest signal. Evolutionary Ecology 8: 248-255.

NuR, N. 1984. The consequences of brood size for breeding Blue Tits II: nestling weight, offspring survival, and optimal brood size. Journal of Animal Ecology 53:497-517.

O'Connor, R. J. 1977. Differential growth and body composition in altricial passerines. Ibis 119:147166.

Palmer, A. R., and C. Strobeck. 1986. Fluctuating asymmetry: measurement, analysis, patterns. Annual Review of Ecology and Systematics 17:391421.

PARSONS, P. A. 1990. Fluctuating asymmetry: an epigenetic measure of stress. Biological Review 65: 131-145.

PARSONS, P. A. 1992. Fluctuating asymmetry: a biological monitor of environmental and genomic stress. Heredity 68:361-364.

Perrins, C. M. 1991. Tits and their caterpillar food supply. Ibis 133,Suppl. I:49-54.

SASVÁRI, L. 1986. Reproductive effort of widowed birds. Journal of Animal Ecology 55:553-564.

StARCK, J. M., AND R. E. Ricklefs [EDS.]. 1998. Avian growth and development. Evolution within the al- tricial-precocial spectrum. Oxford University Press, Oxford, UK.

StatSoft, Inc. 1999. STATISTICA for Windows version 5.5. StatSoft Inc, Tulsa, OK.

SwaddLe, J. P., AND M. S. WitTER. 1994. Food, feathers and fluctuating asymmetries. Proceedings of the Royal Society of London Series B 255:147152.

Swaddle, J. P., AND M. S. WitTer. 1997. On the ontogeny of developmental stability in a stabilized trait. Proceedings of the Royal Society of London Series B 264:329-334.

Swaddle, J. P., M. S. Witter, AND I. C. Cuthill. 1994. The analysis of fluctuating asymmetry. Animal Behaviour 48:986-989.

Teather, K. 1996. Patterns of growth and asymmetry in nestling Tree Swallows. Journal of Avian Biology 27:302-310.

ToMkINS, J. L. 1999. The ontogeny of asymmetry in earwig forceps. Evolution 53:157-163.

VAN BALEN, J. H. 1973. A comparative study of the breeding ecology of the Great Tit Parus major in different habitats. Ardea 61:1-93.

VAN NOORDWIJK, A. J., J. H. VAN BALEN, AND W. SCHARLOO. 1988. Heritability of body size in a natural population of the Great Tit (Parus major) and its relation to age and environmental conditions during growth. Genetical Research Cambridge 51:149-162.

VAN VALEN, L. 1962. A study of fluctuating asymmetry. Evolution 16:125-142.

ZaKharov, V. M. 1992. Population phenogenetics: analysis of developmental stability in natural populations. Acta Zoologica Fennica 191:7-30.

\title{
QUALITY OF FOOD SOURCE AFFECTS FEMALE VISITATION AND DISPLAY RATES OF MALE BROAD-TAILED HUMMINGBIRDS
}

\author{
Alaine F. CAMFiElD ${ }^{1}$ \\ School of Natural Resources and Environment, University of Michigan, Dana Building, 430 E. University, \\ Ann Arbor, MI 48109-1115
}

\begin{abstract}
I studied the relationships among energy availability, female visitation rates, and male display rates in Broad-tailed Hummingbirds (Selasphorus platycercus). Feeders contained $10 \%, 20 \%$, or $30 \%$ sucrose solutions; female visitation rates and male hummingbird display rates were measured. Display rates of male Broad-tailed Hummingbirds and visitation rates of females depended on the quality of the food source.
\end{abstract}

Manuscript received 23 May 2002; accepted 12 February 2003.

${ }^{1}$ E-mail: camfield@umich.edu
The fact that male display rates matched female visitation rates provides further evidence that dive displays play a role in courtship. More work needs to be done to determine if the relationship between resource quality, female visitation, and male display rates shows a threshold contingent on food availability.

Key words: Broad-tailed Hummingbird, display rates, female visitation, food quality, Selasphorus platycercus.

La Calidad de los Recursos Alimenticios Afecta las Tasas de Visita de las Hembras y de 